\title{
ECOLOGICALLY AND ECONOMICALLY SUSTAINABLE AGRICULTURAL TRANSPORTATION BASED ON ADVANCED INFORMATION TECHNOLOGIES
}

\author{
Tibor Fazekaš ${ }^{1}$, Dušan Bobera ${ }^{2}$, Zoran Cirič ${ }^{3}$
}

\begin{abstract}
Summary
In the modern world there are lots of considerations about transportation in general, including analysis and decision making about the current situation and planning as well, that means preparation for future needs through defining policies, goals and investments to design transportation networks and facilities. The environmental consequences of general transportation and agriculture itself are of special interest as well. Transport activities are given and unavoidable in every society, for any country, but their intensive practice often produces negative effects on surroundings. The quoted problem emerges in a special manner when observing merged - as agricultural transportation: modeling ecological issues here is particularly complex due to great number of variables and random elements dependent on subjectivity in decision making, appearance of unexpected events and often incorrect data. In this paper authors discuss different aspects of agricultural transportation and point out the importance of application of methods and models that are capable of treating uncertainties and are appropriate to keep under control the abundance of ecological effects of transportation in agriculture, making efforts towards the development of sustainable food and raw materials production.
\end{abstract}

Key words: agricultural transportation, environmental effects, optimization models

JEL: Q51, R42, C02

\section{Introduction}

In the economy of production of goods and provision of services supply chain has a broad meaning encompassing demand management, supply management, capacity plans,

1 Tibor Fazekaš M.A., Ph.D. student at University of Novi Sad, Faculty of Economics in Subotica, S. Miletića Street no. 70, Subotica, Phone: +381-24-525-896, E-mail: ftibi9@gmail.com.

2 Dušan Bobera Ph.D., Full professor, University of Novi Sad, Faculty of Economics in Subotica, Segedinski put no. 9-11, 24000 Subotica, Serbia, Phone: +381-24-628-000, E-mail: bobera@ef.uns.ac.rs.

3 Zoran Ćirić, Ph.D., Associate Professor, University of Novi Sad, Faculty of Economics in Subotica, Segedinski put no. 9-11, 24000 Subotica, Serbia, Phone: +381-24-628-000, E-mail: czoran@ef.uns.ac.rs.

EP 2017 (64) 2 (739-751) 
strategic procurement, scheduling and logistics as well. In this context logistics as a term mainly incorporates the processes of movement - transportation of goods, services and information between different locations by all kinds of means. Planning, implementing and controlling the optimal inbound-, internal- and outbound flow of goods in agricultural production is very specific compared to other economic activities due to characteristics of agricultural goods, seasonality, strictly set time schedule, large quantities all at once, serious losses during transportation, combination of short and long distances for transportation using connecting roads to and from the field, storehouses, collection-center warehouses, storage buildings of the processing industry, retailers etc. Intensified mobility of goods in agriculture has negative environmental consequences, through emission of pollutants and negative impact on soil quality. While analyzing costs of transportation, for the total real value environmental costs should be taken into account as well. The aim of this paper is to propose application of programming models for agricultural transportation model improvement, taking into account numerous technological and economic constraints with acceptable level of environmental impact while minimizing the sum of relative deviations from individual optimums of different either supportive or competitive goal functions.

\section{Environmental impact of agriculture and agricultural transportation}

General long term plans have to incorporate long term development of the agro system, which only can exist and possess long-lasting productivity under the conditions of ensuring its sustainability. Agricultural sustainability encompasses economic, social and environmental sustainability, while environmental sustainability as a way to maintain the global ecosystem is unconditional requirement for other two items. Over the last few decades the attitude of producers, analysts, decision makers and public opinion towards agriculture has seriously changed. Before the 1970s the main topic of investigations was problems and enhancement of productivity of human-made inputs, while due to increasing and widespread pollution problems as a consequence of intensification of agricultural production methods the majority of attention was redirected towards setting an acceptable level of ecological impact and to how to ensure its realization (van der Werf, Petit, 2002).

In FAO Statistical Yearbook 2013 in Part 4 about sustainability dimensions of World food and agriculture the land and forestry, water, biodiversity, agro-environmental indicators, organic farming, bio-based economy, climate change and greenhouse gas emissions are analyzed. Natural resource management is mainly connected to agricultural human activities: $30 \%$ of land is used for agricultural production and $70 \%$ of all freshwater use of the World is designated to agricultural production, so this threatens air, soils and water. Agriculture is the main source of chemical pollution and emissions of greenhouse gases. The dependence is mutual: negative ecological impact of agriculture has the consequence of negative impact of damaged environment on the quantity and quality of agricultural production and the agricultural resources will further be reduced. FAO's research connected to land and forestry contains main issues about soil degradation and deforestation; connected to water the main problems analyzed is the annual withdrawal of fresh water, which has risen for more than six times in one hundred years - from the beginning of the 
twentieth to the beginning of the twenty-first century. Biodiversity is under pressure from the intensification of agricultural production (FAO, 2013).

A very serious ecological problem arises from greenhouse gas emission, while human activities are responsible for almost all of the increase in greenhouse gases in the atmosphere over the last 150 years (IPPC, 2007). According to EPA the main sources of emissions in the USA in 2014 are electricity production (with share of 30\%), transportation (26\%), industry (21\%), commercial and residential (as for heating and waste handling, 12\%) and agriculture (9\%) (EPA, 2014). Globally, the share of transportation is $23.3 \%$ in average for the World (IEA, 2016). The World's leading country of dangerous emissions is China with almost one quarter of all quantities, then the next are USA, EU, India, Russia and so on (WRI, 2014). The short term and long-term negative consequences should be reduced, and any effort made towards achieving that goal is desirable.

There are lots of problematic ecological issues in all segments of human life and activities. Soil degradation caused by in-field transport represents a serious problem in agricultural production, and that leads to reduction of production and overall soil sustainability. Several projects were elaborated to deal with this problem, for example the SOCOMO soil compaction model intended to calculate soil stresses and the subsoil carrying capacity (van den Akker, 2004) and a decision support system built up to evaluate the severity of soil compaction (Marx et al., 2006). One of the projects aimed to reduce significant transport costs in agriculture is development of a sugarcane transport route planning model "FastTrack" aimed to determine the path between any number of points in space based on geographical information system; the reason supporting this project is the fact of significant transport costs, while the objective is to formulate such a design (including existing and new specialized roads) by which optimum in terms of efficiency and economics could be found, including minimum cost, maximum travel speed, safety and minimal environmental impact. (Harris, 2008).

Klenk et al., published key findings of their investigations accomplished about the carbon footprint of sugar production form beet in the EU compared to that of cane sugar imported and consumed in the EU. The project was prepared for the European Association of Sugar Manufacturers (CEFS). The study ventures relevant agro-ecological aspects of sustainable production. Ecological impacts of transport were given a great importance, i.e. the average distance from field to sugar mills is $45 \mathrm{~km}$ in the EU while the transport cycle of raw cane sugar involves greater distances; here transport and refining are responsible to $45-61 \%$ of total emissions. (Klenk, 2012).

\section{Main problems of efficient and effective agricultural transportation}

Hereby we quote an interesting and important statement about agricultural transportation: "Transport is regarded as a crucial factor in improving agricultural productivity. It enhances quality of life of the people, creates market for agricultural produce, and facilitates interaction among geographical and economic regions and open up new areas to economic focus." (Ajiboye, Afolayan, 2009). 
By the definition of FAO "Transport generally marks the passage from one stage of the post-harvest system to the next. Transport, whether traditional or mechanized, is needed to move the agricultural commodities:

- $\quad$ from the harvest fields to the threshing or drying site;

- from there to the farmer's storehouses or to collection-center warehouses;

- from there to the processing industries or to bigger central storage buildings (often much farther from where the commodity is grown);

- from these industries or storage buildings to wholesalers or retailers for final marketing." (FAO, 2017)

Agricultural transportation activities encompasses the movement of:

“ - materials and supplies such as feed, bedding, fertilizer, seed, plant materials, pest control products, and fuel

- farm products such as fruit, vegetables, hay, feed, processed or unprocessed farm goods, live animals, birds and plants

- wastes such as compost, manure, spent plant material and growing media, mortalities, plastics, and spoiled feed

- people, including employees, contract workers, farm supply representatives, service providers and customers

- equipment”. (MABC, 2014).

Numerous studies and official documents point to the importance of the rational/ optimal organization of transportation in agriculture, and considerable are the results of implementation of software products which enable efficient and effective transportation, taking into account various factors with the general aim to ensure continuous supply and cost reduction. In its document about agricultural transport FAO emphasizes: "The transport system must be as economical and effective as possible. This implies strict planning for the use of vehicles, according to transport priorities of certain products, establishment of certain schedules, and availability of personnel... Good transport planning must take account of the location of collection points, processing and storage centers, and markets, of the distances separating them, and of the quantities of products to be loaded or unloaded at each point." (FAO, 2017).

The Strategy of agricultural and rural development of Republic of Serbia for the period 2014-2024 anticipates distribution of agricultural budget; in the part concerning solving of priority problems of sustainable rural development the promotion of agricultural infrastructure is planned involving roads and water supply. Relations between road transport, rural development and food safety, connected to marketing and road freight transport costs are being analyzed in details, and there are several examples of comparative studies of agricultural transportation costs prepared on international level. (e.g. Hine and Ellis, 2001). Although there are lots of different sources of agricultural production costs, it seems the transportation itself comprises great part of them so every effort made 
to reorganize transportation could have economically, socially and ecologically positive results. Some calculations show that almost half of all costs of agricultural production are derived from transport activities within farms or from transportation of goods between farms and the external market (Turan, 2005). Reduction of costs of agricultural transportation is being realized in different ways and various methods, e.g. redesigning road design and loading zones (Bezuidenhout et al., 2004); undertaking an assessment of farm transportation system and investigating distances from farmers' residence to farm location and to delivery place for their products, road conditions and use of private and commercial transportation means and considering combinations of direct deliveries to consumption areas and setting up up collection centers and warehouses on farm areas (Mijinyawa, Adetunji, 2005); elaborating of agricultural supply chain-, agro-forestry supply chain- and sugar supply chain modeling, calculating with the use of different loading and transport equipment (Stutterheim, 2006). Using of a computer simulation model of an agricultural vehicle-park consisting of different transport means the stability analysis of different vehicle combination is enabled; by introducing stability criteria equations for future stability control programs different unstable states can be determined and the vehicle combinations can be re-stabilized (Szakacs, 2010). When considering decision support systems built for agricultural managers it must be emphasized the role and importance of transport as an expensive operation, which has large impact on the quality of products, needs special collaboration of all the participants, and transport i.e. supply scheduling system has the most impact on supply chain as a whole (Lyne, 2012). There are examples where the impact of transport on agricultural development is assessed through answers to questionnaires given directly by farmers; from one of these surveys the conclusion was derived that transport conditions impact the agriculture of the whole area and bad road conditions raise transport costs and thus strongly affect the income of farmers (Tunde and Adeyini, 2012). Global problems of agricultural transportation in a country may be derived from the wider location of production regions related to urban centers and export facilities; this is case for example for USA where there are great distances between supply sites and consumption places, so movement of agricultural products use all possible transport facilities and represent serious competition to other freight transportation needs (Mayne, 2015). For every component of the agro-food supply chain, namely transport, storage, warehousing, handling and information flow, a set of key performance indicators can be derived; main indicators for transport in agro-food supply chain include charging time, ontime delivery, truck capacities, distances trucks make empty, idle times, maintenance- and repairing time, deviation from schedule, fuel consumption etc. (Dinu, 2016). Under the commission of NAMC (National Agricultural Marketing Council of Australia) the report "The Role of Transport in Logistics of Agriculture" was compiled for South Africa by Max Braun Consulting Services. The objective of this report was to identify and define the key transport cost drivers with impact on agricultural logistics. Their findings include: the transport from farm gate to consumer is complex; the value chains are well diversified concerning size, location, distances and road conditions; transport costs impact on rural development. (Max Brown CS, 2010). 


\section{Modeling agricultural transportation}

The area of technical, economic, social, environmental etc. problems resulting from transportation is especially complex and any attempt to model this system has to calculate with great number of random elements as consequences of subjectivity in concerns and decision making, appearance of unexpected events and not satisfactory correctness of data; these in a similar manner and perhaps more expressed appear in agricultural transportation. The starting point in organization of transportation is the determination of efficient and effective use of vehicles and drivers employed on existing and new communication facilities. The known procedures result in the minimum number of vehicles, the minimum number of drivers and the minimal total road length. These calculations obtain rational use of resources and expectantly contribute to the reduction of negative ecological effects of transportation.

To satisfy the needs for environmentally sustainable transport in agriculture industry an environmentally sustainable supply chain for agriculture has been developed, and opportunities for innovations were defined, which could reduce some of negative impacts on the environment using fuzzy performance analysis (Leigh and Li 2015). Agricultural products need to be transported and kept in storage in an adequate way, and connected to that question it is very important to evaluate the supply chain risk; one possible access is given by the application of the TOPSIS method combined with the entropy method to the supply chain risk evaluation in agricultural production and transport (Wang and Hao, 2016). The Agtrix, an Australian company provides sophisticated technology solutions for agricultural sector particularly in the area of supply chain. Their product FREDD is a traffic scheduling system that maintains a continuous supply of agricultural product to a milling location managing the trips for the fleet of trucks that supply that mill. This decision support system is aimed to minimize transport costs through the number of trucks, and calculates with several inputs as mill crushing rate, average bin weight, changes in trip time due to variable road conditions such as fog, rain, holiday traffic and road works and the number of trucks available at any time, to allow for breakdowns. (Agtrix, 2017). The Australian Government is planning to make transport for agriculture more efficient and thus invests about AUD 50 billion in high quality infrastructure for agricultural production. For transport costs make up more than $20 \%$ of products' value, better infrastructure will reduce total costs through shorter delivery times and lower vehicle operating costs. (Australian Government, 2017).

As mentioned above various methods and models have been proposed aimed at solving serious transportation problems in agriculture. In case of all known variables with exact values deterministic programming models find application to optimize routing problems. On the other hand in the real word general data and so data related to transportation are by their nature uncertain that can be treated as stochastic vehicle routing problem starting from randomness and probability distribution and construct either a chance constrained program or a stochastic program with resources (Brito et al., 2012). Random elements are inevitably present in modeling of transportation in agriculture, so the classical terms and methods of mathematical statistics, probability theory and mathematical programming are satisfactory neither for theory nor for the real life performances in complex situations filled 
with randomness. Other theories are needed to solve these problems, enable model building and obtain solutions, especially when there are subjective attitudes and expert opinions, and it is not possible precisely to define model parameters. To relax these shortcomings one of the possibilities is to apply a special theory based on fuzzy sets.

Traditional way of computer programming is based on binary evaluations like yes/no, true/ false or zero/one, but much closer to human way of thinking is to allow intermediate values between these two opposites, and this is enabled by fuzzy logic. In classical mathematics there are strictly separated elements that belong to crisp sets and the membership function takes a value of zero or one. On the contrary fuzzy logic uses fuzzy sets where membership function can indicate "more or less" belonging to a set and can take any value between 0 and 1; also this means that some elements belong to overlapping sets. In his seminal work "Fuzzy Sets" Zadeh begins with the next: "A fuzzy set is a class of objects with a continuum of grades of membership. Such a set is characterized by a membership (characteristic) function which assigns to each object a grade of membership ranging between zero and one." (Zadeh, 1965). Originally the fuzzy logic was intended to model human activities, but it can be also applied for development of automatic control systems. (Mamdani, 1974). Zimmermann quotes a variety of applications of fuzzy sets and fuzzy logic: "artificial intelligence, computer science, medicine, control engineering, decision theory, expert systems, logic, management science, operations research, pattern recognition, and robotics..., computational intelligence or soft computing." (Zimmermann, 2010).

Fuzzy set theory can be successfully applied to transportation investment project selection problems where multi objectives are given (Tzeng et al., 1993). Meixner used Fuzzy Analytic Hierarchy Process in the evaluation process of road network elements reconstruction versions (Meixner, 2009). The importance of weights of all multi-criteria assessment the weight evaluation gain wider meaning by using fuzzy variables (Danka, 2011). It is convenient to apply fuzzy technique to simultaneously minimize total costs of production and transportation along with minimization of total delivery time, subject to budgetary and supply constraints, given transportation vehicles- and warehouse capacities with forecasted demand (David, Pandian, 2011). The three-dimensional concept of sustainability (social, economic and environmental) of transportation politics is elaborated and formalized by using the fuzzy-based evaluation method (Rossi et al., 2012). Akumu et al., developed a technique to model and map soil depth classes based on GIS-fuzzy logic modeling; this approach was performed based on the soil-environment model (Akumu et al., 2016). A new fuzzy-stochastic multiple criteria decision-making method was proposed by researches intended for water resources management while taking into account various economic criteria, environmental and ecological dimensions (Subagadis et al., 2016). Some authors used hesitant fuzzy sets to present a possible application in the area of human resources allocation (Ciric et al., 2015). The fuzzy Delphi method is applicable in the process of analyzing performance levels in the problems of agricultural management encompassing transportation problems as well (Lin and Yang, 2016). A modified fuzzy hybrid genetic algorithm was proposed to establish scheduling model of the use of agricultural machinery from the resource centers of farms, in various situations considering time, weather and road 
factors (Luo and Zhang, 2016). The fuzzy importance-preference analysis is unavoidable in studying eco-innovations in agriculture for here preferences are described by linguistic variables and the qualitative attributes include subjective and objective preferences (Horng, Lin 2013; Chen 2016). Some authors used the expanded and changed decision making system, by developing and installing a new fuzzificated model for decision making tree in farm management. In the model with several inputs and one output input elements on the lower level become fuzzy. The outcome of the model is a specific decision, which is influenced by a considerable number of factors and the soundness of assumptions. This model could simulate sustainable functioning of farm management (Sedlak et al, 2011).

\section{Conclusions}

The importance of agricultural transportation resulted in numerous and various theoretical and practical studies about different aspects of this problem. In this paper authors tried to present organization of agricultural transportation as determined by efficacious and beneficial use of facilities on existing and new potentials, while the goal is to maximize production and to keep negative ecological effects under control in the same time; the aim is to make the whole reproduction cycle in agriculture sustainable. In farm management in real-life situations in the field of agricultural transportation any attempt of modelling and optimization is limited by the fact that very often the equations for most linear or non-linear processes are unknown and therefore approximations are unavoidable. Input data to the model are not precisely determined or not exactly known; constraints cannot be explained precisely enough, and the goal function cannot be clearly defined; there is a lack of precise information on the value of individual input parameters, on the values of coefficients in constraint and goal functions; an imprecise formulation of limitations themselves is possible as well. The nature of the agricultural transportation problem represents the features of uncertainty and vagueness and for all these reasons the introduction of fuzzy sets into the existing decision making models in several ways is recommended.

\section{References}

1. Agtrix (2017): Products - Transport - FREDD, Agtrix Pty Ltd Australia (available at: http://www.agtrix.com/index.php?option=com_k2\&view= item\&layout $=$ item $\& \mathrm{id}=179 \&$ Itemid=617\#FREDD), Billinudgel, Australia

2. Ajiboye, A. O., Afolayan, O. (2009): The impact of transportation on agricultural production in a developing country: a case of kola nut production in Nigeria, International Journal on Agricultural Economics and Rural Development, Vol. 2, No. 2, pp. 49-57, Gujarat, India

3. Akumu, C. E., Woods, M., Johnson, J. A., Pitt, D. G., Uhlig, P., McMurray, S. (2016): GIS-fuzzy logic technique in modeling soil depth classes: Using parts of the Clay Belt and Hornepayne region in Ontario, Canada as a case study, Elsevier, Geoderma, CCLXXXIII, pp. 78-87, DOI: 10.1016/j.geoderma.2016.07.028, Amsterdam, The Netherlands 
4. Australian Government (2017): Agricultural Competiveness White Paper, Canberra, Australia, (available at http://agwhitepaper.agriculture.gov.au/)

5. Balanovskaya, T.I., Boretska, Z.P. (2014): Application of fuzzy inference system to increase efficiency of management decision-making in agricultural enterprises, Scientific Journal- Problems of World Agriculture, Vol. 29, No. 4, pp. 15-24, Warsaw University of Life Sciences, Poland

6. Bezuidenhout, C.N., Lusso, C.D., Lyne, P.W.L., Meyer, E. (2004): Minimising transport costs through optimal upgrading of roads and loading zones. Proceedings of the 78th South African Sugar Technologists' Association - SASTA Congress, 2004, pp. 103-112, Durban, South Africa

7. Brito, J., Moreno, J.A., Verdegay, J.L. (2012): Transport Route Planning Models Based on Fuzzy Approach, Iranian Journal of Fuzzy Systems, Vol. 9, No. 1, pp. 141-158, University of Sistan and Baluchestan, Iran

8. Chen, C.A. (2016): How can Taiwan create a niche in Asia's cruise tourism industry? Tourism Management, 55, pp. 173-183. Elsevier Ltd.

9. Ćirić, Z., Stojić, D., Sedlak, O. (2015): Multicriteria HR allocation based on hesitant fuzzy sets and possibilistic programming. ACTA POLYTECHNICA HUNGARICA, Vol. 12, No. 3, pp. 185-197, Óbuda University, Budapest, Hungary

10. Danka, S. (2011): Robust Resource Constrained Project Scheduling with Fuzzy Activity Durations. Pollack Periodica, Akademiai Kiado, Vol. 3, pp. 131-142, Budapest, Hungary

11. David, P., Pandian, V. (2011): Transportation planning with modified S-curve membership functions using an interactive fuzzy multi-objective approach. Applied Soft Computing, 11, pp. 2656-2663.

12. Dinu, M.D. (2016): Supply chain performance within agri food sector. Economics of Agriculture, The Balkan Scientific Association of Agrarian Economists, Belgrade, Institute of Agricultural Economics, Belgrade, Serbia and Academy of Economic Studies, Bucharest, Romania, Vol. 63, No. 3, pp. 919-928, Belgrade

13. Food and agriculture organization of the United Nations (2013): FAO Statistical Yearbook 2013, FAO, Rome, Italy

14. Food and agriculture organization of the United Nations (2017): Transport, FAO, Rome, Italy (available at: http://www.fao.org/docrep/t0522e/T0522E0f.htm)

15. Harris A.J., Bezuidenhout C.N., Lagrange L.F., Lyne, P.W.L. (2008): Development of a sugarcane transport route planning model in a geographical information system. Proceedings of the 81st South African Sugar Technologists' Association SASTA Congress, pp. 430-433, Durban, South Africa

16. Hine, J.L., Ellis, S.D. (2001): Agricultural marketing and access to transport Services, Rural Travel and Transport Program 2001, World bank, Washington DC. (available at: https://www.ssatp.org/sites/ssatp/files/publications/HTML/rural trans port/knowledge_base/English/Module\%204/4_3a\%20Agricultural\%20 
Marketing.pdf)

17. Horng, J.S., Lin, L. (2013): Training needs assessment in a hotel using 360 degree feedback to develop competency-based training programs. Journal of Hospitality and Tourism Management, 20, pp. 61-67, Elsevier Ltd.

18. Intergovernmental Panel on Climate Change - IPCC (2007): Summary for Policymakers, In: Climate Change 2007: The Physical Science Basis, Contribution of Working Group I to the Fourth Assessment Report of the Intergovernmental Panel on Climate Change [Solomon, S., D. Qin, M. Manning, Z. Chen, M. Marquis, K.B. Averyt, M. Tignor and H.L. Miller (eds.)]. Cambridge University Press, Cambridge, United Kingdom and New York, NY, USA. (available at: http:// www.ipcc.ch/publications_and_data/ar4/wg1/en/sp

19. International Energy Agency - IEA (2016): CO2 Emissions from Fuel Combustion, Organisation for Economic Co-operation and Development, Paris, France (available at: /www.iea.org/publications/freepublications/publication/CO2 EmissionsfromFuelCombustion_Highlights_2016.pdf)

20. Jovanic, T. (2013): Agri-environmental legislative framework in Serbiain light of the harmonization with EU law, Economics of Agriculture, II, pp. 321-335

21. Klenk, I., Landquist, B., de Imaña, O.R. (2012): The Product Carbon Footprint of EU Beet Sugar, Sugar Industry Journal, CEFS, Vol. 137, No. 62, pp. 1-23, Brusseles, Belgium

22. Leigh, M., Li, X. (2015): Industrial ecology, industrial symbiosis and supply chain environmental sustainability: a case study of a large UK distributor. Journal of Cleaner Production, 106, pp. 632-643. Elsevier Ltd.

23. Lin, M.C., Yang, M.W. (2016): Investment Evaluation of Tourism Industry: A Case Study of Coastal Recreation Areas in Hualien Taiwan. International Business Research, 9(12), pp. 1-12, Canadian Center of Science and Education.

24. Luo, X. W., Zhang, L. Y., (2016): The Optimal Scheduling Model for Agricultural Machinery Resources with Time-Window Constraints, International Journal of Simulation Modelling, DAAAM International Vienna, Vol. 15, No. 4, pp. 721731, DOI: 10.2507/IJSIMM15(4)CO17, Wien, Austria

25. Lyne, P.W.L.(2012): Decision support systems for sugarcane production managers, Proceedings of the 85th South African Sugar Technologists'Association - SASTA Congress, pp. 206-220, Durban, South Africa

26. MABC - Ministry of Agriculture of British Columbia (2014): Strengthening Farming - Farm Practice - Transportation, No. 870.218-56, Victoria, British Columbia (available at: http:/www2.gov.bc.ca/assets/gov/farmingnatural-resources-and-industry/agriculture-and-seafood/agricultural-land-andenvironment/strengthening-farming/farm-practices/870218-56_transportation. pdf)

27. Mamdani, E.H. (1974): Applications of fuzzy algorithms for control of simple 
dynamic plant, Proceedings of the Institution of Electrical Engineers, Vol. 121, Issue 12, pp. 1584 - 1588, New York, USA2

28. Marx, B.J., Bezuidenhout, C.N., Lyne, P.W.L., van Antwerpen, R. (2006): Soil compaction decision support, Proceedings of the 80th South African Sugar Technologists' Association - SSTA Congress, pp. 104-107, Durban, South Africa

29. Max Brown CS (2010): The role of transport in logistics of agriculture, National Agricultural Marketing Council of Australia (available at: http://www.namc. co.za/ upload/input_cost_monitoring/The\%20Role\%20of\%20Transport\%20in $\% 20$ Logistics\%20of\% 20 Agriculture.pdf)

30. Mayne, C. (2015): Agricultural transportation challenges, NASCO, Windsor, Texas Department of transportation (available at: http://nasconetwork.com/ Websites/nasconetwork/images/AGRICULTURE_TRANSPORTATION.pdf)

31. Meixner, O. (2009): Fuzzy AHP Group Decision Analysis and its Application for the Evaluation of Energy Sources. Proceedings of the 10th International Symposium on the Analytic Hierarchy/Network Process Multi-criteria Decision Making, University of Pittsburgh, Pittsburgh, Pennsylvania, USA, (available at: http://www.isahp.org/2009Proceedings/Final_Papers/50_Meixner_Fuzzy_AHP_ REV_FIN.pdf, Feb. 15, 2017)

32. Rossi, R., Gastaldi, M., Gecchele, G. (2012): Sustainability evaluation of transportation policies: a fuzzy-based method in a "what to" analysis. Online Conference on Soft Computing in Industrial Applications, Technical University of Ostrava, Czech Republic

33. Sedlak, O., Kočić Vugdelija, V., Kudumović, M., Bešić, C., Đorđević, D. (2011): Management of family farms - Implementation of Fuzzy method in short-term planning. TTEM - Technics Technologies Education Management Journal, Vol. 5 (3), 2010, pp. 710-719. DRUNPP Sarajevo BiH

34. Stutterheim, P. (2006): An integrated sugarcane supply chain model: development and demonstration, MSc dissertation, University of KwaZulu-Natal Pietermaritzburg South Africa

35. Subagadis, Y.H., Schutze, N., Grundmann, J. (2016): A Fuzzy-Stochastic Modeling Approach for Multiple Criteria Decision Analysis of Coupled GroundwaterAgricultural Systems, Water Resources Management, Springer, Vol. 30, No. 6, pp. 2075-2095, DOI: 10.1007/s11269-016-1270-5, New York City, USA

36. Szakacs, T. (2010): Developing Stability Control Theories for Agricultural Transport Systems. Acta Polytechnica Hungarica, Vol. 7, No. 2, pp. 25-37. Obuda University, Budapest, Hungary

37. Tunde, A.M., Adeniyi, E.E. (2012): Impact of road transport on agricultural development: a Nigerian example, Ethiopian Journal of Environmental Studies and Management, V(3), pp. 232-238, Department of Geography and Environmental Studies, Bahir Dar University, Ethiopia (available at: http://www.ajol.info/index. php /ejesm/article/view/77955/68350) 
38. Turan, J. (2005): Masovni transport u poljoprivredi. Poljoprivredna tehnika. Poljoprivredni fakultet, Institut za poljoprivrednu tehniku, Novi Sad, Vol. 30, No. 1, pp. 85-89, Novi Sad, Srbija

39. Tzeng, G.H., Teng, J.Y. (1993): Transportation investment project selection with fuzzy multiobjectives, Transportation Planning and Technology, Vol. 17, No. 2, pp. 91-112, Francis and Teylor Online

40. United States Environmental Protection Agency - EPA (2014): U.S. Greenhouse Gas Inventory Report: 1990-2014 (available at: https://www.epa.gov/ghg emissions/us- greenhouse-gas-inventory-report-1990-2014)

41. van den Akker, J.J.H. (2004): SOCOMO: A soil compaction model to calculate soil stresses and the subsoil carrying capacity, Soil and Tillage Research, Elsevier, Vol. 79, No. 1, pp. 113-127, Amsterdam, Netherlands

42. van der Werf, H.M.G., Petit, J. (2002): Evaluation of the environmental impact of agriculture at the farm level: a comparison and analysis of 12 indicator-based methods, Agriculture, Ecosystems \& Environment, Vol. 93, No. 1-3, pp. 131-145, Elsevier, Amsterdam, Netherlands, (available at: http://www.sciencedirect.com / science/article/pii/S0167880901003541)

43. Wang, Y., Hao, H. (2016): Research on the Supply Chain risk Assessment of the Fresh Agricultural Products based on the Improved TOPTSIS Algorithm. 3rd International Conference on Applied Engineering, Book Series: Chemical Engineering Transactions, 51, pp. 445-450, Wuhan, PR China

44. World Resources Institute - WRI (2014): Climate Analysis Indicators Tool, Washington, DC (available at: http://cait2.wri.org/) 


\title{
EKOLOŠKI I EKONOMSKI ODRŽIVI POLJOPRIVREDNI TRANSPORT ZASNOVAN NA SAVREMENIM INFORMACIONIM TEHNOLOGIJAMA
}

\author{
Tibor Fazekaš̆, Dušan Bobera ${ }^{5}$, Zoran Ćirić ${ }^{6}$
}

\section{Rezime}

Sadašnje doba obiluje različitim razmatranjima o transportu uopšte, uključujući analizu $i$ donošenje odluka u vezi sa postojećom situacijom kao i planiranjem, u smislu priprema za buduće potrebe putem definisanja politika, ciljeva kao i ulaganja u dizajn transportne mreže i transportnih sredstava. Uticaj na okolinu transporta uopšte, a posebno poljoprivrednog transporta su od posebne važnosti. Transpoprtne aktivnosti su date i neizostavne delatnosti za svako društvo i zemlju, međutim, intenziviranje transporta veoma često ima negativne posledice po okolinu. Navedeni problem se javlja s posebnom težinom kod poljoprivrednog transporta: modeliranje, koje uključuje i ekološke probleme je u ovom slučaju naročito složeno zbog veoma velikog broja varijabli i slučajnih elemenata koji zavise od subjektivnosti u procesu donošenja odluka, zbog pojave neočekivanih događaja, $i$, veoma često, zbog netačnih $i$ nedovoljno preciznih polaznih podataka. U ovom radu autori razmatraju različite aspekte poljoprivrednog transporta $i$ ukazuju na korišćenje takvih postupaka $i$ metoda kojima se mogu tretirati neizvesnost i pomoću kojih se mogu kontrolisati nepovoljni ekološki efekti poljoprivrednog transporta, što doprinosi unapređenju održivog sistema proizvodnje hrane i sirovina.

Ključne reči: poljoprivredni transport, ekološki efekti, modeli optimizacije

4 Tibor Fazekaš M.A., Student doktorskih studija Univerziteta u Novom Sadu, Ekonomski fakultet u Subotici, Ulica S. Miletića br. 70, Subotica, Srbija, Telefon: +381 24525896 , E-mail: ftibi9@gmail.com.

5 Redovni profesor, dr Dušan Bobera, Univerzitet u Novom Sadu, Ekonomski fakultet u Subotici, Segedinski put br. 9-11, 24000 Subotica, Srbija, Telefon: +381 24628000 , E-mail: bobera@ef.uns.ac.rs.

6 Vanredni profesor, dr Zoran Ćirić, Univerzitet u Novom Sadu, Ekonomski fakultet u Subotici, Segedinski put br. 9-11, 24000 Subotica, Srbija, Telefon: +381-24-628-000, E-mail: czoran@ef.uns.ac.rs.

EP 2017 (64) 2 (739-751) 